\title{
Vienna Declaration and Programme of Action ${ }^{1}$
}

\author{
The World Conference on Human Rights,
}

Considering that the promotion and protection of human rights is a matter of priority for the international community, and that the Conference affords a unique opportunity to camy out a comprehensive analysis of the intemational human rights system and of the machinery for the protection of human rights, in order to enhance and thus promote a fuller observance of those rights, in a just and balanced manner,

Recognizing and affirning that all human rights derive from the dignity and worth inherent in the human person, and that the human person is the central subject of human rights and fundamental freedoms, and consequently should be the principal beneficiary and should participate actively in the realization of these rights and freedoms,

Reaffirming their commitment to the purposes and principles contained in the Charter of the United Nations and the Universal Declaration of Human Rights,

Reaffirming the commitment contained in Article 56 of the Charter of the United Nations to take joint and separate action, placing proper emphasis on developing effective intemational cooperation for the realization of the purposes set out in Article 55, including universal respect for, and observance of, human rights and fundamental freedoms for all,

Emphasizing the responsibilities of all States, in conformity with the Charter of the United Nations, to develop and encourage respect for human rights and fundamental freedoms for all, without distinction as to race, sex, language or religion,

Recalling the Preamble to the Charer of the United Nations, in particular the determination to reaf firm faith in fundamental human rights, in the dignity and worth of the human person, and in the equal rights of men and women and of nations large and small,

Recalling also the determination expressed in the Preamble of the Charter of the United Nations to save succeeding generations from the scourge of war, to establish conditions under which justice and respect for obligations arising from treaties and other sources of intemational law can be maintained, to promote social progress and better standards of life in larger freedom, to practice tolerance and good neighbourliness, and to employ intemational machinery for the promotion of the economic and social advancement of all peoples,

Emphasizing that the Universal Declaration of Human Rights, which constitutes a common standard of achievement for all peoples and all nations, is the source of inspiration and has been the basis for the United Nations in making advances in standard setting as contained in the existing intemational human rights instruments, in particular the International Covenant on Civil and Political Rights and the International Covenant on Economic, Social and Cultural Rights,

Considering the major changes taking place on the intemational scene and the aspirations of all the peoples for an intemational order based on the principles enshrined in the Charter of the United

1 Adopted by the World Conference on Human Rights at Vienna on 25 June 1993. Deutsche Übersetzung in EuGRZ 1993, $520 \mathrm{ff}$. 
Nations, including promoting and encouraging respect for human rights and fundamental freedorns for all and respect for the principle of equal rights and self-determination of peoples, peace, democracy, justice, equality, nule of law, pluralism, development, better standards of living and solidarity,

Deeply concerned by various forms of discrimination and violence, to which women continue to be exposed all over the world,

Recognizing that the activities of the United Nations in the field of human rights should be rationalized and enhanced in order to strengthen the United Nations machinery in this field and to further the objectives of universal respect for observance of intemational human rights standards,

Having taken into account the Declarations adopled by the three regional meetings at Tunis, San José and Bangkok and the contributions made by Govemments, and bearing in mind the suggestions made by intergovemmental and non-govemmental organizations, as well as the studies prepared by independent experts during the preparatory process leading to the World Conference on Human Rights,

Welcoming the International Year of the World's Indigenous People 1993 as a reaffirmation of the cornmitment of the intemational community to ensure their enjoyment of all human rights and fundamental freedorns and to respect the value and diversity of their cultures and identities,

Recognizing also that the intemational community should devise ways and means to remove the current obstacles and meet challenges to the full realization of all human rights and to prevent the continuation of human rights violations resulting thereof throughout the world,

Invoking the spirit of our age and the realities of our time which call upon the peoples of the world and all States Members of the United Nations to rededicate themselves to the global task of promoting and protecting all human rights and fundamental freedoms so as to secure full and universal enjoyment of these rights,

Determined to take new steps forward in the commitment of the international community with a view to achieving substantial progress in human rights endeavours by an increased and sustained effor of intemationalcooperation and solidarity,

Solemnly adopts the Vienna Declaration and Programme of Action.

I.

1. The World Conference on Human Rights reaffirms the solemn commitment of all States to fulfil their obligations to promote universal respect for, and observance and protection of, all human rights and fundamental freedoms for all in accordance with the Charter of the United Nations, other instruments relating to human rights, and international law. The universal nature of these rights and freedoms is beyond question.

In this framework, enhancement of intemational cooperation in the field of human rights is essential for the full achievement of the purposes of the United Nations.

Human rights and fundamental freedoms are the birthright of all human beings; their protection and promotion is the first responsibility of Governments.

2. All peoples have the right of self-determination. By virtue of that right they freely determine their political status, and freely pursue their economic, social and cultural development.

Taking into account the particular situation of peoples under colonial or other forms of alien domination or foreign occupation, the World Conference on Human Rights recognizes 
the right of peoples to take any legitimate action, in accordance with the Charter of the United Nations, to realize their inalienable right of self-determination. The World Conference on Human Rights considers the denial of the right of self-determination as a violation of human rights and underlines the importance of the effective realization of this right. In accordance with the Declaration on Principles of International Law conceming Friendly Relations and Cooperation Among States in accordance with the Charter of the United Nations, this shall not be construed as authorizing or encouraging any action which would dismember or impair, totally or in part, the territorial integrity or political unity of sovereign and independent States conducting themselves in compliance with the principle of equal rights and self-determination of peoples and thus possessed of a Govemment representing the whole people belonging to the territory without distinction of any kind.

3. Effective international measures to guarantee and monitor the implementation of human rights standards should be taken in respect of people under foreign occupation, and effective legal protection against the violation of their human rights should be provided, in accordance with human rights norms and international law, particularly the Geneva Convention relative to the Protection of Civilian Persons in Time of War, of 14 August 1949, and other applicable noms of humanitarian law.

4. The promotion and protection of all human rights and fundamental freedoms must be considered as a priority objective of the United Nations in accordance with its purposes and principles, in particular the purpose of intemational cooperation. In the framework of these purposes and principles, the promotion and protection of all human rights is a legitimate concern of the international community. The organs and specialized agencies related to human rights should therefore further enhance the coordination of their activities based on the consistent and objective application of international human rights instruments.

5. All human rights are universal, indivisible and interdependent and interrelated. The international community must treat human rights globally in a fair and equal manner, on the same footing, and with the same emphasis. While the significance of national and regional particularities and various historical, cultural and religious backgrounds must be borne in mind, it is the duty of States, regardless of their political, economic and cultural systems, to promote and protect all human rights and fundamental freedoms.

6. The efforts of the United Nations system towards the universal respect for, and observance of, human rights and fundamental freedoms for all, contribute to the stability and well-being necessary for peaceful and friendly relations among nations, and to improved conditions for peace and security as well as social and economic development, in conformity with the Charter of the United Nations.

7. The processes of promoting and protecting human rights should be conducted in conformity with the purposes and principles of the Charter of the United Nations, and international law.

8. Democracy, development and respect for human rights and fundamental freedoms are interdependent and mutually reinforcing. Democracy is based on the freely expressed will of the people to determine their own political, economic, social and cultural systems and 
their full participation in all aspects of their lives. In the context of the above, the promotion and protection of human rights and fundamental freedoms at the national and international levels should be universal and conducted without conditions attached. The international community should support the strengthening and promoting of democracy, development and respect for human rights and fundamental freedoms in the entire world.

9. The World Conference on Human Rights reaffirms that least developed countries committed to the process of democratization and economic reforms, many of which are in Africa, should be suppored by the international community in order to succeed in their transition to democracy and economic development.

10. The World Conference on Human Rights reaffirms the right to development, as established in the Declaration on the Right to Development, as a universal and inalienable right and an integral part of fundamental human rights.

As stated in the Declaration on the Right to Development, the human person is the central subject of development.

While development facilitates the enjoyment of all human rights, the lack of development may not be invoked to justify the abridgement of internationally recognized human rights.

States should cooperate with each other in ensuring development and eliminating obstacles to development. The intemational community should promote an effective intemational cooperation for the realization of the right to development and the elimination of obstacles to development.

Lasting progress towards the implementation of the right to development requires effective development policies at the national level, as well as equitable economic relations and a favourable economic environment at the international level.

11. The right to development should be fulfilled so as to meet equitably the developmental and environmental needs of present and future generations. The World Conference on Human Rights recognizes that illicit dumping of toxic and dangerous substances and waste potentially constitutes a serious threat to the human rights to life and health of everyone. Consequently, the World Conference on Human Rights calls on all States to adopt and vigorously implement existing conventions relating to the dumping of toxic and dangerous products and waste and to cooperate in the prevention of illicit dumping.

Everyone has the right to enjoy the benefits of scientific progress and its applications. The World Conference on Human Rights notes that certain advances, notably in the biomedical and life sciences as well as in information technology, may have potentially adverse consequences for the integrity, dignity and human rights of the individual, and calls for international cooperation to ensure that human rights and dignity are fully respected in this area of universal concem.

12. The World Conference on Human Rights calls upon the international community to make all efforts to help alleviate the external debt burden of developing countries, in order to supplement the efforts of the Governments of such countries to attain the full realization of the economic, social and cultural rights of their people.

13. There is a need for States and international organizations, in cooperation with nongovernmental organizations, to create favourable conditions at the national, regional and 
intemational levels to ensure the full and effective enjoyment of human rights. States should eliminate all violations of human rights and their causes, as well as obstacles to the enjoyment of these rights.

14. The existence of widespread extreme poverty inhibits the full and effective enjoyment of human rights; its immediate alleviation and eventual elimination must remain a high priority for the international community.

15. Respect for human rights and for fundamental freedoms without distinction of any kind is a fundamental rule of international human rights law. The speedy and comprehensive elimination of all forms of racism and racial discrimination, xenophobia and related intolerance is a priority task for the international community. Governments should take effective measures to prevent and combat them. Groups, institutions, intergovernmental and nongovernmental organizations and individuals are urged to intensify their efforts in cooperating and coordination their activities against these evils.

16. The World Conference on Human Rights welcomes the progress made in dismantling apartheid and calls upon the international community and the United Nations system to assist in this process.

The World Conference on Human Rights also deplores the continuing acts of violence aimed at undermining the quest for a peaceful dismantling of apartheid.

17. The acts, methods and practices of terrorism in all its forms and manifestations as well as linkage in some countries to drug trafficking are activities aimed at the destruction of human rights, fundamental freedoms and democracy, threatening territorial integrity, security of States and destabilizing legitimately constituted Governments. The international community should take the necessary steps to enhance cooperation to prevent and combat terrorism.

18. The human rights of women and of the girl-child are an inalienable, integral and indivisible part of universal human rights. The full and equal participation of women in political, civil, economic, social and cultural life, at the national, regional and intemational levels, and the eradication of all forms of discrimination on grounds of sex are priority objectives of the international community.

Gender-based violence and all forms of sexual harassment and exploitation, including those resulting from cultural prejudice and intemational trafficking, are incompatible with the dignity and worth of the human person, and must be eliminated. This can be achieved by legal measures and through national action and international cooperation in such fields as economic and social development, education, safe matemity and health care, and social support.

The human rights of women should form an integral part of the United Nations human rights activities, including the promotion of all human rights instruments relating to women. The World Conference on Human Rights urges Govemments, institutions, intergovernmental and non-governmental organizations to intensify their efforts for the protection and promotion of human rights of women and the girl-child. 
19. Considering the importance of the promotion and protection of the rights of persons belonging to minorities and the contribution of such promotion and protection to the political and social stability of the States in which such persons live.

The World Conference on Human Rights reaf firms the obligations of States to ensure that persons belonging to minorities may exercise fully and effectively all human rights and fundamental freedoms without any discrimination and in full equality before the law in accordance with the Declaration on the Rights of Persons Belonging to National or Ethnic, Religious and Linguistic Minorities.

The persons belonging to minorities have the right to en joy their own culture, to profess and practise their own religion and to use their own language in private and in public, freely and without interference or any form of discrimination.

20. The World Conference on Human Rights recognizes the inherent dignity and the unique contribution of indigenous people to the development and plurality of society and strongly reaffirms the commitment of the intemational community to their economicc, social and cultural well-being and their enjoyment of the fruits of sustainable development. States should ensure the full and free participation of indigenous people in all aspects of society, in particular matters of concem to them. Considering the importance of the promotion and protection of the rights of indigenous people, and the contribution of such promotion and protection to the political and social stability of the States in which such people live, States should, in accordance with international law, take concerted positive steps to ensure respect for all human rights and fundamental freedoms of indigenous people, on the basis of equality and non-discrimination, and recognize the value and diversity of their distinct identities, cultures and social organization.

21. The World Conference on Human Rights, welcoming the early ratification of the Convention on the Rights of the Child by a large number of States and noting the recognition of the human rights of children in the World Declaration on the Survival, Protection and Development of Children and Plan of Action adopted by the World Summit for Children, urges universal ratification of the Convention by 1995 and its effective implementation by States parties through the adoption of all the necessary legislative, administrative and other measures and the allocation to the maximum extent of the available resources. In all actions concerning children, non-disccrimination and the best interest of the child should be primary considerations and the views of the child given due weight. National and international mechanisms and programmes should be strengthened for the defence and protection of children, in particular, the girl-child, abandoned children, street children, economically and sexually exploited children, including through child pomography, child prostitution or sale of organs, children victims of diseases including acquired immunodeficiency syndrome, ref ugee and displaced children, children in detention, children in armed conflict, as well as children victims of famine and drought and other emergencies. Intemational cooperation and solidarity should be promoted to support the implementation of the Convention and the rights of the child should be a priority in the United Nations system-wide action on human rights. 
The World Conference on Human Rights also stresses that the child for the full and harmonious development of his or her personality should grow up in a family environment which accordingly merits broader protection.

22. Special attention needs to be paid to ensuring non-discrimination, and the equal enjoyment of all human rights and fundamental freedoms by disabled persons, including their active participation in all aspects of society.

23. The World Conference on Human Rights reaffirms that everyone, without distinction of any kind, is entitled to the right to seek and to enjoy in other countries asylum from persecution, as well as the right to return to one's own country. In this respect it stresses the importance of the Universal Declaration of Human Rights, the 1951 Convention relating to the Status of Refugees, its 1967 Protocol and regional instruments. It expresses its appreciation to States that continue to admit and host large numbers of refugees in their territories, and to the Office of the United Nations High Commissioner for Refugees for its dedication to its task. It also expresses its appreciation to the United Nations Relief and Works Agency for Palestine Refugees in the Near East.

The World Conference on Human Rights recognizes that gross violations of human rights, including in armed conflicts, are among the multiple and complex factors leading to displacement of people.

The World Conference on Human Rights recognizes that, in view of the complexities of the global refugee crisis and in accordance with the Charter of the United Nations, relevant international instruments and international solidarity and in the spirit of burden-sharing, a comprehensive approach by the international community is needed in coordination and cooperation with the countries concerned and relevant organizations, bearing in mind the mandate of the United Nations High Commissioner for Refugees. This should include the development of strategies to address the root causes and effects of movements of refugees and other displaced persons, the strengthening of emergency preparedness and response mechanisms, the provision of effective protection and assistance, bearing in mind the special needs of women and children, as well as the achievement of durable solutions, primarily through the preferred solution of dignified and safe voluntary repatriation, including solutions such as those adopted by the international refugee conferences. The World Conference on Human Rights underlines the responsibilities of States, particularly as they relate to the countries of origin.

In the light of the comprehensive approach, the World Conference on Human Rights emphasizes the importance of giving special attention including through intergovernmental and humanitarian organizations and finding lasting solutions to questions related to internally displaced persons including their voluntary and safe return and rehabilitation.

In accordance with the Charter of the United Nations and the principles of humanitarian law, the World Conference on Human Rights further emphasizes the imporance of and the need for humanitarian assistance to victims of all natural and man-made disasters.

24. Great importance must be given to the promotion and protection of the human rights of persons belonging to groups which have been rendered vulnerable, including migrant workers, the elimination of all forms of discrimination against them, and the strengthening and more effective implementation of existing human rights instruments. States have an 
obligation to create and maintain adequate measures at the national level, in particular in the fields of education, health and social support, for the promotion and protection of the rights of persons in vulnerable sectors of their populations and to ensure the participation of those among them who are interested in finding a solution to their own problems.

25. The World Conference on Human Rights affirms that extreme poverty and social exclusion constitute a violation of human dignity and that urgent steps are necessary to achieve better knowledge of extreme poverty and its causes, including those related to the problem of development, in order to promote the human rights of the poorest, and to put an end to extreme poverty and social exclusion and to promote the enjoyment of the fruits of social progress. It is essential for States to foster participation by the poorest people in the decision-making process by the community in which they live, the promotion of human rights and efforts to combat extreme poverty.

26. The World Conference on Human Rights welcomes the progress made in the codification of human rights instruments, which is a dynamic and evolving process, and urges the universal ratification of human rights treaties. All States are encouraged to accede to these international instruments; all States are encouraged to avoid, as far as possible, the resort to reservations.

27. Every State should provide an effective framework of remedies to redress human rights grievances or violations. The administration of justice, including law enforcement and prosecutorial agencies and, especially, an independent judiciary and legal profession in full conformity with applicable standards contained in international human rights instruments, are essential to the full and non-discriminatory realization of human rights and indispensable to the processes of democracy and sustainable development. In this context, institutions concemed with the administration of justice should be properly funded, and an increased level of both technical and financial assistance should be provided by the international community. It is incumbent upon the United Nations to make use of special programmes of advisory services on a priority basis for the achievement of a strong and independent administration of justice.

28. The World Conference on Human Rights expresses its dismay at massive violations of human rights especially in the form of genocide, "ethnic cleansing" and systematic rape of women in war situations, creating mass exodus of refugees and displaced persons. While strongly condemning such abhorrent practices it reiterates the call that perpetrators of such crimes be punished and such practices immediately stopped.

29. The World Conference on Human Rights expresses grave concern about continuing human rights violations in all parts of the world in desregard of standards as contained in intemational human rights instruments and intemational humanitarian law and about the lack of sufficient and effective remedies for the victims.

The World Conference on Human Rights is deeply concerned about violations of human rights during armed conflicts, affecting the civilian population, especially women, children, the elderly and the disabled. The Conference therefore calls upon States and all parties to armed conflicts strictly to observe international humanitarian law, as set forth in the Geneva 
Conventions of 1949 and other rules and principles of intemational law, as well as minimum standards for protection of human rights, as laid down in intemational conventions.

The World Conference on Human Rights reaffirms the right of the victims to be assisted by humanitarian organizations, as set forth in the Geneva Convention of 1949 and other relevant instruments of international humanitarian law, and calls for the safe and timely access for such assistance.

30. The World Conference on Human Rights also expresses its dismay and condemnation that gross and systematic violations and situations that constitute serious obstacles to the full enjoyment of all human rights continue to occur in different parts of the world. Such violations and obstacles include, as well as cornure and cruel, inhuman and degrading treatment or punishment, summary and arbitrary executions, disappearances, arbitrary detentions, all forms of racism, racial discrimination and apartheid, foreign occupation and alien domination, xenophobia, poverty, hunger and other denials of economic, social and cultural rights, religious intolerance, terrorism, discrimination against women and lack of the rule of law.

31. The World Conference on Human Rights calls upon States to refrain from any unilateral measure not in accordance with intemational law and the Charter of the United Nations that creates obstacles to trade relations among States and impedes the full realization of the human rights set forth in the Universal Declaration of Human Rights and international human rights instruments, in particular the rights of everyone to a standard of living adequate for their health and well-being, including food and medical care, housing the necessary social services. The World Conference on Human Rights affirms that food should not be used as a tool for political pressure.

32. The World Conference on Human Rights reaffirms the importance of ensuring the universality, objectivity and non-selectivity of the consideration of human rights issues.

33. The World Conference on Human Rights reaffirms that States are duty-bound, as stipulated in the Universal Declaration on Human Rights and the Intemational Covenant on Economic, Social and Cultural Rights and in other international human rights instruments, to ensure that education is aimed at strenthening the respect of human rights and fundamental freedoms. The World Conference on Human Rights emphasizes the importance of incorporating the subject of human rights education programmes and calls upon States to do so. Education should promote understanding, tolerance, peace and friendly relations between the nations and all racial or religious groups and encourage the development of United Nations activities in pursuance of these objectives. Therefore, education on human rights and the dissemination of proper information, both theoretical and practical, play an important role in the promotion and respect of human rights with regard to all individuals without distinction of any kind such as race, sex, language or religion, and this should be integrated in the education policies at the national as well as international levels. The World Conference on Human Rights notes that resource constraints and institutional inadequacies may impede the immediate realization of these objectives.

34. Increased efforts should be made to assist countries which so request to create the conditions whereby each individual can enjoy universal human rights and fundamental free- 
doms. Governments, the United Nations system as well as other multilateral organizations are urged to increase considerably the resources allocated to programmes aiming at the establishment and strengthening of national legislation, national institutions and related infrastructures which uphold the rule of law and democracy, electoral assistance, human rights awareness through training, teaching and education, popular participation and civil society.

The programmes of advisory services and technical cooperation under the Centre for Human Rights should be strengthened as well as made more efficient and transparent and thus become a major contribution to improving respect for human rights. States are called upon to increase their contributions to these programmes, both through promoting a larger allocation from the United Nations regular budget, and through voluntary contributions.

35. The full and effective implementation of United Nations activities to promote and protect human rights must reflect the high imporance accorded to human rights by the Charter of the United Nations and the demands of the United Nations human rights activities, as mandated by Member States. To this end, United Nations human rights activities should be provided with increased resources.

36. The World Conference on Human Rights reaffirms the important and constructive role played by national institutions for the promotion and protection of human rights, in particular in their advisory capacity to the competent authorities, their role in remedying human rights violations, in the dissemination of human rights information, and education in human rights.

The World Conference on Human Rights encourages the establishment and strengthening of national institutions, having regard to the "Principles relating to the status of national institutions" and recognizing that it is the right of each State to choose the framework which is best suited to its particular needs at the national level.

37. Regional arrangements play a fundamental role in promoting and protecting human rights. They should reinforce universal human rights standards, as contained in international human rights instruments, and their protection. The World Conference on Human Rights endorses efforts under way to strengthen these arrangements and to increase their effectiveness, while at the same time stressing the importance of cooperation with the United Nations human rights activities.

The World Conference on Human Rights reiterates the need to consider the possibility of establishing regional and subregional arrangements for the promotion and protection of human rights where they do not already exist.

38. The World Conference on Human Rights recognizes the important role of non-governmental organizations in the promotion of all human rights and in humanitarian activities at national, regional and international levels. The World Conference on Human Rights appreciates their contribution to increasing public awareness of human rights issues, to the conduct of education, training and research in this field, and to the promotion and protection of all human rights and fundamental freedoms. While recognizing that the primary responsibility for standard-setting lies with States, the conference also appreciates the contribution of non-governmental organizations to this process. In this respect, the World Con- 
ference on Human Rights emphasizes the importance of continued dialogue and cooperation between Governments and non-governmental organizations. Non-govemmental organizations and their members genuinely involved in the field of human rights should enjoy the rights and freedoms recognized in the Universal Declaration of Human Rights, and the protection of the national law. These rights and freedoms may not be exercised contrary to the purposes and principles of the United Nations. Non-governmental organizations should be free to carry out their human rights activities, without interference, within the framework of national law and the Universal Declaration of Human Rights.

39. Underlining the importance of objective, responsible and impartial information about human rights and humanitarian issues, the World Conference on Human Rights encourages the increased involvement of the media, for whom freedom and protection should be guaranteed within the framework of national law.

\section{II.}

\section{A. Increased coordination on human rights within the United Nations system}

1. The World Conference on Human Rights recommends increased coordination in support of human rights and fundamental freedoms within the United Nations system. To this end, the World Conference on Human Rights urges all United Nations organs, bodies and the specialized agencies whose activities deal with human rights to cooperate in order to strengthen, rationalize and streamline their activities, taking into account the need to avoid unnecessary duplication. The World Conference on Human Rights also recommends to the Secretary-General that high-level officials of relevant United Nations bodies and specialized agencies at their annual meeting, besides coordinating their activities, also assess the impact of their strategies and policies on the enjoyment of all human rights.

2. Furthermore, the World Conference on Human Rights calls on regional organizations and prominent international and regional finance and development institutions to assess also the impact of their policies and programmes on the enjoyment of human rights.

3. The World Conference on Human Rights recognizes that relevant specialized agencies and bodies and institutions of the United Nations system as well as other relevant intergovernmental organizations whose activities deal with human rights play a vital role in the formulation, promotion and implementation of human rights standards, within their respective mandates, and should take into account the outcome of the World Conference on Human Rights within their fields of competence.

4. The World Conference on Human Rights strongly recommends that a concerted effort be made to encourage and facilitate the ratification of and accession or succession to international human rights treaties and protocols adopted within the framework of the United Nations system with the aim of universal acceptance. The Secretary-General, in consultation with treaty bodies, should consider opening a dialogue with States not having acceded to these human rights treaties, in order to identify obstacles and to seek ways of overcoming them. 
5. The World Conference on Human Rights encourages States to consider limiting the extent of any reservations they lodge to international human rights instruments, formulate any reservations as precisely and narrowly as possible, ensure that none is incompatible with the object and purpose of the relevant treaty and regularly review any reservations with a view to withdrawing them.

6. The World Conference on Human Rights, recognizing the need to maintain consistency with the high quality of existing intemational standards and to avoid proliferation of human rights instruments, reaffirms the guidelines relating to the elaboration of new international instruments contained in General Assembly resolution 41/120 of 4 December 1986 and calls on the United Nations human rights bodies, when considering the elaboration of new international standards, to keep those guidelines in mind, to consult with human rights treaty bodies on the necessity for drafting new standards and to request the Secretariat to carry out technical reviews of proposed new instruments.

7. The World Conference on Human Rights recommends that human rights officers be assigned if and when necessary to regional offices of the United Nations Organization with the purpose of disseminating information and offering training and other technical assistance in the field of human rights upon the request of concemed Member States. Human rights training for intemational civil servants who are assigned to work relating to human rights should be organized.

8. The World Conference on Human Rights welcomes the convening of emergency sessions of the Commission on Human Rights as a positive initiative and that other ways of responding to acute violations of human rights be considered by the relevant organs of the United Nations system.

\section{Resources}

9. The World Conference on Human Rights, concemed by the growing disparity between the activities of the Centre for Human Rights and the human, financial and other resources available to carry them out, and bearing in mind the resources needed for other important United Nations programmes, request the Secretary-General and the General Assembly to take immediate steps to increase substantially the resources for the human rights programme from within the existing and future regular budgets of the United Nations, and to take urgent steps to seek increased extrabudgetary resources.

10. Within this framework, an increased proportion of the regular budget should be allocated directly to the Centre for Human Rights to cover its costs and all other costs bome by the Centre for Human Rights, including those related to the United Nations human rights bodies. Voluntary funding of the Centre's technical cooperation activities should reinforce this enhanced budget; the World Conference on Human Rights calls for generous contributions to the existing trust funds.

11. The World Conference on Human Rights requests the Secretary-General and the General Assembly to provide sufficient human, financial and other resources to the Centre for Human Rights to enable it effectively, efficiently and expeditiously to carry out its activities. 
12. The World Conference on Human Rights, noting the need to ensure that human and financial resources are available to carry out the human rights activities, as mandated by intergovernmental bodies, urges the Secretary-General, in accordance with Article 101 of the Charter of the United Nations, and Member states to adopt a coherent approach aimed at securing that resources commensurate to the increased mandates are allocated to the Secretariat. The World Conference on Human Rights invites the Secretary-General to consider whether adjustments to procedures in the programme budget cycle would be necessary or helpful to ensure the timely and effective implementation of human rights activities as mandated by Member states.

Centre for Hunan Rights

13. The World Conference on Human Rights stresses the importance of strengthening the United Nations Centre for Human Rights.

14. The Centre for Human Rights should play an important role in coordinating systemwide attention for human rights. The focal role of the Centre can best be realized if it is enabled to cooperate fully with other United Nations bodies and organs. The coordinating role of the Centre for Human Rights also implies that the office of the Centre for Human Rights in New York is strengthened.

15. The Centre for Human Rights should be assured adequate means for the system of thematic and country r aypureurs, experts, working groups and treaty bodies. Follow-up on recommendation should become a priority matter for consideration by the Commission on Human Rights.

16. The Centre for Human Rights should assume a larger role in the promotion of human rights. This role could be given shape through cooperation with Member States and by an enhanced programme of advisory services and technical assistance. The existing voluntary funds will have to be expanded substantially for these purposes and should be managed in a more efficient and coordinated way. All activities should follow strict and transparent project management rules and regular programme and project evaluations should be held periodically. To this end, the results of such evaluation exercises and other relevant information should be made available regularly. The Centre should, in particular, organize at least once a year information meetings open to all Member States and organizations directly involved in these projects and programmes.

Adaptation and strengthening of the United Nations machinery for hwman rights, including the question of the establishment of a United Nations High Commissioner for Human Rights

17. The World Conference on Human Rights recognizes the necessity for a continuing adaptation of the United Nations human rights machinery to the current and future needs in the promotion and protection of human rights, as reflected in the present Declaration and within the framework of a balanced and sustainable development for all people. In particular, the United Nations human rights organs should improve their coordination, efficiency and effectiveness. 
18. The World Conference on Human Rights recommends to the General Assembly that when examining the report of the Conference at its forty-eighth session, it begin, as a matter of priority, consideration of the question of the establishment of a High Commissioner for Human Rights for the promotion and protection of all human rights.

\section{B. Equality, dignity and tolerance}

\section{Racism, racial discrimination, xenophobia and other forms of intolerance}

19. The World Conference on Human Rights considers the elimination of racism and racial discrimination, in particular in their institutionalized forms such as apartheid or resulting from doctrines of racial superiority or exclusivity or contemporary forms and manifestations of racism, as a primary objective for the international community and a worldwide promotion programme in the field of human rights. United Nations organs and agencies should strengthen their efforts to implement such a programme of action related to the third decade to combat racism and racial discrimination as well as subsequent mandates to the same end. The World Conference on Human Rights strongly appeals to the international community to contribute generously to the Trust Fund for the Programme for the Decade for Action to Combat Racism and Racial Discrimination.

20. The World Conference on Human Rights urges all Govemments to take immediate measures and to develop strong policies to prevent and combat all forms and manifestations of racism, xenophobia or related intolerance, where necessary by enactment of appropriate legislation, including penal measures, and by the establishment of national institutions to combat such phenomena.

21. The World Conference on Human Rights welcomes the decision of the Commission on Human Rights to appoint a Special Rapporteur on contemporary forms of racism, racial discrimination, xenophobia and related intolerance. The World Conference on Human Rights also appeals to all States parties to the International Convention on the Elimination of All Forms of Racial Discrimination to consider making the declaration under article 14 of the Convention.

22. The World Conference on Human Rights calls upon all Governments to take all appropriate measures in compliance with their international obligations and with due regard to their respective legal systems to counter intolerance and related violence based on religion or belief, including practices of discrimination against women and including the desecration of religious sites, recognizing that every individual has the right to freedom of thought, conscience, expression and religion. The Conference also invites all States to put into practice the provisions of the Declaration on the Elimination of All Forms of Intolerance and of Discrimination Based on Religion or Belief.

23. The World Conference on Human Rights stresses that all persons who perpetrate or authorize criminal acts associated with ethnic cleansing are individually responsible and accountable for such human rights violations, and that the international community should exert every effort to bring those legally responsible for such violations to justice. 
24. The World Conference on Human Rights calls on all States to take immediate measures, individually and collectively, to combat the practice of ethnic cleansing to bring it quickly to an end. Victims of the abhorrent practice of ethnic cleansing are entitled to appropriate and effective remedies.

\section{Persons belonging to national or ethnic, religious and linguistic minorities}

25. The World Conference on Human Rights calls on the Commission on Human Rights to examine ways and means to promote and protect effectively the rights of persons belongig to minorities as set out in the Declaration on the Rights of Persons belonging to National or Ethnic, Religious and Linguistic Minorities. In this context, the World Conference on Human Rights calls upon the Centre for Human Rights to provide, at the request of Govemments concemed and as part of its programme of advisory services and technical assistance, qualified expertise on minority issues and human rights, as well as on the prevention and resolution of disputes, to assist in existing or potential situations involving minorities.

26. The World Conference on Human Rights urges States and the international community to promote and protect the rights of persons belonging to national or ethnic, religious and linguistic minorities in accordance with the Declaration on the Rights of Persons belonging to National or Ethnic, Religious and Linguistic Minorities.

27. Measures to be taken, where appropriate, should include facilitation of their full participation in all aspects of the political, economic, social, religious and cultural life of society and in the economic progress and development in their country.

\section{Indigenous people}

28. The World Conference on Human Rights calls on the Working Group on Indigenous Populations of the Sub-Commission on Prevention of Discrimination and Protection of Minorities to complete the drafting of a declaration on the rights of indigenous people at its eleventh session.

29. The World Conference on Human Rights recommends that the Commission on Human Rights consider the renewal and updating of the mandate of the Working Group on Indigenous Populations upon completion of the drafting of a declaration on the rights of indigenous people.

30. The World Conference on Human Rights also recommends that advisory services and technical assistance programmes within the United Nations system respond positively to requests by States for assistancce which should be of direct benefit to indigenous people. The World Conference on Human Rights further recommends that adequate human and financial resources be made available to the Centre for Human Rights within the overall framework of strengthening the Centre's activities as envisaged by this document.

31. The World Conference on Human Rights urges States to ensure the full and free participation of indigenous people in all aspects of society, in particular in matters of concern to them. 
32. The World Conference on Human Rights recommends that the General Assembly proclaim an international decade of the world's indigenous people, to begin from January 1994, including action-orientated programmes, to be decided upon in partnership with indigenous people. An appropriate voluntary trust fund should be set up for this purpose. In the framework of such a decade, the establishment of a permanent forum for indigenous people in the United Nations system should be considered.

\section{Migrant workers}

33. The World Conference on Human Rights urges all States to guarantee the protection of the human rights of all migrant workers and the ir families.

34. The World Conference on Human Rights considers that the creation of conditions to foster greater harmony and tolerance between migrant workers and the rest of the society of the State in which they reside is of particular importance.

35. The World Conference on Human Rights invites States to consider the possibility of signing and ratifying, at the earliest possible time, the International Convention on the Rights of All Migrant Workers and Members of Their Families.

\section{The equal status and hwnar rights of women}

36. The World Conference on Human Rights urges the full and equal enjoyment by women of all human rights and that this be a priority for Governments and for the United Nations. The World Conference on Human Rights also underlines the importance of the integration and full participation of women as both agents and beneficiaries in the development process, and reiterates the objectives established on global action for women towards sustainable and equitable development set forth in the Rio Declaration on Environment and Development and chapter 24 of Agenda 21, adopted by the United Nations Conference on Environment and Development (Rio de Janeiro, Brazil, 3-14 June 1992).

37. The equal status of women and the human rights of women should be integrated into the mainstream of United Nations system-wide activity. These issues should be regularly and systematically addressed throughout relevant United Nations bodies and mechanisms. In particular, steps should be taken to increase cooperation and promote further integration of objectives and goals between the Commission on the Status of Women, the Commission on Human Rights, the Committee for the Elimination of Discrimination against Women, the United Nations Development Fund for Women, the United Nations Development Programme and other United Nations agencies. In this context, cooperation and coordination should be strengthened between the Centre for Human Rights and the Division for the Advancement of Women.

38. In particular, the World Conference on Human Rights stresses the importance of working towards the elimination of violence against women in public and private life, the elimination of all forms of sexual harassment, exploitation and trafficking in women, the elimination of gender bias in the administration of justice and the eradication of any conflicts which may arise between the rights of women and the harmful effects of certain traditional or customary practices, cultural prejudices and religious extremism. The World Conference on Human Rights calls upon the General Assembly to adopt the draft declara- 
tion on violence against women and urges States to combat violence against women in accordance with its provisions. Violations of the human rights of women in situations of armed conflict are violations of the fundamental principles of intemational human rights and humanitarian law. All violations of this kind, including in particular murder, systematic rape, sexual slavery, and forced pregnancy, require a particularly effective response.

39. The World Conference on Human Rights urges the eradication of all forms of discrimination against women, both hidden and overt. The United Nations should encourage the goal of universal ratification by all States of the Convention on the Elimination of All Forms of Discrimination against Women by the year 2000. Ways and means of addressing the particularly large number of reservations to the Convention should be encouraged. Inter alia, the Committee on the Elimination of Discrimination against Women should continue its review of reservations to the Convention. States are urged to withdraw reservations that are contrary to the object and purpose of the Convention or which are otherwise incompatible with international treaty law.

40. Treaty monitoring bodies should disseminate necessary information to enable women to make more effective use of existing implementation procedures in their pursuits of full and equal enjoyment of human rights and non-discrimination. New procedures should also be adopted to strengthen implementation of the commitment to women's equality and the human rights of women. The Commission on the Status of Women and the Committee on the Elimination of Discrimination against Women should quickly examine the possibility of introducing the right of petition through the preparation of an optional protocol to the Convention on the Elimination of All Forms of Discrimination against Women. The World Conference on Human Rights welcomes the decision of the Commission on Human Rights to consider the appointment of a special rapporeur on violence against women at its fiftieth session.

41. The World Conference on Human Rights recognizes the importance of the enjoyment by women of the highest standard of physical and mental health throughout their life span. In the context of the World Conference on Women and the Convention on the Elimination of All Forms of Discrimination against Women, as well as the Proclamation of Tehran of 1968, the World Conference on Human Rights reaffirms, on the basis of equality between women and men, a woman's right to accessible and adequate health care and the widest range of family planning services, as well as equal access to education at all levels.

42. Treaty monitoring bodies should include the status of women and the human rights of women in their deliberations and findings, making use of gender-specific data. States should be encouraged to supply information on the situation of women de jure and de facto in their reports to treaty monitoring bodies. The World Conference on Human Rights notes with satisfaction that the Commission on Human Rights adopted at its forty-ninth session resolution 1993/46 of 8 March 1993 stating that rapporteurs and working groups in the field of human rights should also be encouraged to do so. Steps should also be taken by the Division for the Advancement of Women in cooperation with other United Nations bodies, specifically the Centre for Human Rights, to ensure that the human rights activities of the United Nations regularly address violations of women's human rights, including gender- 
specific abuses. Training for United Nations human rights and humanitarian relief personnel to assist them to recognize and deal with human rights abuses particular to women and to carry out their work without gender bias should be encouraged.

43. The World Conference on Human Rights urges Governments and regional and international organizations to facilitate the access of women to decision-making posts and their greater participation in the decision-making process. It encourages further steps within the United Nations Secretariat to appoint and promote women staff members in accordance with the Charter of the United Nations, and encourages other principal and subsidiary organs of the United Nations to guarantee the participation of women under conditions of equality.

44. The World Conference on Human Rights welcomes the World Conference on Women to be held in Beijing in 1995 and urges that human rights of women should play an important role in its deliberations, in accordance with the priority themes of the World Conference on Women of equality, development and peace.

\section{The rights of the child}

45. The World Conference on Human Rights reiterates the principle of "First Call for Children" and, in this respect, underlines the importance of major national and intemational efforts, especially those of the United Nations Children's Fund, for promoting respect for the rights of the child to survival, protection, development and participation.

46. Measures should be taken to achieve universal ratification of the Convention on the Rights of the Child by 1995 and the universal signing of the World Declaration on the Survival, Protection and Development of Children and Plan of Action adopted by the World Summit for Children, as well as their effective implementation. The World Conference on Human Rights urges States to withdraw reservations to the Convention the the Rights of the Child contrary to the object and purpose of the Convention or otherwise contrary to international treaty law.

47. The World Conference on Human Rights urges all nations to undertake measures to the maximum extent of their available resources, with the support of international cooperation, to achieve the goals in the World Summit Plan of Action. The Conference calls on States to integrate the Convention on the Rights of the Child into their national action plans. By means of these national action plans and through international efforts, particular priority should be placed on reducing infant and matemal mortality rates, reducing malnutrition and illiteracy rates and providing access to safe drinking water and to basic education. Whenever so called for, national plans of action should be devised to combat devastating emergencies resulting from natural disasters and armed conflicts and the equally grave problem of children in extreme poverty.

48. The World Conference on Human Rights urges all States, with the support of international cooperation, to address the acute problem of children under especially difficult circumstances. Exploitation and abuse of children should be actively combated, including by addressing their root causes. Effective measures are required against female infanticide, 
harmful child labour, sale of children and organs, child prostitution, child pomography, as well as other forms of sexual abuse.

49. The World Conference on Human Rights supports all measures by the United Nations and its specialized agencies to ensure the effective protection and promotion of human rights of the girl child. The World Conference on Human Rights urges States to repeal existing laws and regulations and remove customs and practices which discriminate against and cause harm to the girl child.

50. The World Conference on Human Rights strongly supports the proposal that the Secretary-General initiate a study into means of improving the protection of children in armed conflicts. Humanitarian norms should be implemented and measures taken in order to protect and facilitate assistance to children in war zones. Measures should include protection for children against indiscriminate use of all weapons of war, especially antipersonnel mines. The need for aftercare and rehabilitation of children traumatized by war must be addressed urgently. The Conference calls on the Committee on the Rights of the Child to study the question of raising the minimum age of recruitment into armed forces.

51. The World Conference on Human Rights recommends that matters relating to human rights and the situation of children be regularly reviewed and monitored by all relevant organs and mechanisms of the United Nations system and by the supervisory bodies of the specialized agencies in accordance with their mandates.

52. The World Conference on Human Rights recognizes the important role played by nongovernmental organizations in the effective implementation of all human rights instruments and, in particular, the Convention on the Rights of the Child.

53. The World Conference on Human Rights recommends that the Committee on the Rights of the Child, with the assistance of the Centre for Human Rights, be enabled expeditiously and effectively to meet its mandate, especially in view of the unprecedented extent of ratification and subsequent submission of country reports.

\section{Freedom from torture}

54. The World Conference on Human Rights welcomes the ratification by many Member States of the Convention against Torture and Other Cruel, Inhuman or Degrading Treatment or Punishment and encourages its speedy ratification by all other Member States.

55. The World Conference on Human Rights emphasizes that one of the most atrocious violations against human dignity is the act of torture, the result of which destroys the dignity and impairs the capability of victims to continue their lives and their activities.

56. The World Conference on Human Rights reaffirms that under human rights law and international humanitarian law, freedom from torture is a right which must be protected under all circumstances, including in times of intemal or international disturbance or armed conflicts.

57. The World Conference on Human Rights therefore urges all States to put an immediate end to the practice of torture and eradicate this evil forever through full implementation of 
the Universal Declaration of Human Rights as well as the relevant conventions and, where necessary, strengthening of existing mechanisms. The World Conference on Human Rights calls on all States to cooperate fully with the Special Rapporeur on the question of torture in the fulfilment of his mandate.

58. Special attention should be given to ensure universal respect for, and effective implementation of, the Principles of Medical Ethics relevant to the Role of Health Personnel, particularly Physicians, in the Protection of Prisoners and Detainees against Torture and Other Cruel, Inhuman or Degrading Treatment or Punishment adopted by the General Assembly of the United Nations.

59. The World Conference on Human Rights stresses the importance of further concrete action within the framework of the United Nations with the view to providing assistance to victims of torture and ensure more effective remedies for their physical, psychological and social rehabilitation. Providing the necessary resources for this purpose should be given high priority, inter alia, by additional contributions to the United Nations Voluntary Fund for the Victims of Torture.

60. States should abrogate legislation leading to impunity for those responsible for grave violations of human rights such as torture and prosecute such violations, thereby providing a firm basis for the rule of law.

61. The World Conference on Human Rights reaffirms that efforts to eradicate torture should, first and foremost, be concentrated on prevention and, therefore, calls for the early adoption of an optional protocol to the Convention against Torture and Other Cruel, Inhuman or Degrading Treatment or Punishment, which is intended to establish a preventive system of regular visits to places of detention.

\section{Enforced disappearances}

62. The World Conference on Human Rights, welcoming the adoption by the General Assembly of the Declaration on the Protection of All Persons from Enforced Disappearance, calls upon all States to take effective legislative, administrative, judicial or other measures to prevent, terminate and punish acts of enforced disappearances. The World Conference on Human Rights reaffirms that it is the duty of all States, under any circumstances, to make investigations whenever there is reason to believe that an enforced disappearance has taken place on a territory under their jurisdiction and, if allegations are confirmed, to prosecute its perpetrators.

\section{The rights of the disabled person}

63. The World Conference on Human Rights reaffirms that all human rights and fundamental freedoms are universal and thus unreservedly include persons with disabilities. Every person is born equal and has the same rights to life and welfare, education and work, living independently and active participation in all aspects of society. Any direct discrimination or other negative discriminatory treatment of a disabled person is therefore a violation of his or her rights. The World Conference on Human Rights calls on Governments, where necessary, to dopt or adjust legislation to assure access to these and other rights for disabled persons. 
64. The place of disabled persons is everywhere. Persons with disabilities should be guaranteed equal opportunity through the elimination of all socially determined barriers, be they physical, financial, social or psychological, which exclude or restrict full participation in society.

65. Recalling the World Programme of Action concerning Disabled Persons, adopted by the General Assembly at its thinty-seventh session, the World Conference on Human Rights calls upon the General Assembly and the Economic and Social Council to adopt the draft standard rules on the equalization of opporanities for persons with disabilities, at their meetings in 1993.

\section{Cooperation, development and strengthening of human rights}

66. The World Conference on Human Rights recommends that priority be given to national and international action to promote democracy, development and human rights.

67. Special emphasis should be given to measures to assist in the strengthening and building of institutions relating to human rights, strengthening of a pluralistic civil society and the protection of groups which have been rendered vulnerable. In this context, assistance provided upon the request of Governments for the conduct of free and fair elections, including assistance in the human rights aspects of elections and public information about elections, is of particular importance. Equally important is the assistance to be given to the strengthening of the rule of law, the promotion of freedom of expression and the administration of justice, and to the real and effective participation of the people in the decision-making processes.

68. The World Conference on Human Rights stresses the need for the implementation of strengthened advisory services and technical assistance activities by the Centre for Human Rights. The Centre should make available to States upon request assistance on specific human rights issues, including the preparation of reports under human rights treaties as well as for the implementation of coherent and comprehensive plans of action for the promotion and protection of human rights. Strengthening the institutions of human rights and democracy, the legal protection of human rights, training of officials and others, broadbased education and public information aimed at promoting respect for human rights should all be available as components of these programmes.

69. The World Conference on Human Rights strongly recommends that a comprehensive programme be established within the United Nations in order to help States in the task of building and strengthening adequate national structures which have a direct impact on the overall observance of human rights and the maintenance of the rule of law. Such a programme, to be coordinated by the Centre for Human Rights, should be able to provide, upon the request of the interested Government, technical and financial assistance to national projects in reforming penal and correctional establishments, education and training of lawyers, judges and security forces in human rights, and any other sphere of activity relevant to the good functioning of the rule of law. That programme should make available to States assistance for the implementation of plans of action for the promotion and protection of human rights. 
70. The World Conference on Human Rights requests the Secretary-General of the United Nations to submit proposals to the United Nations General Assembly, containing alternatives for the establishment, structure, operational modalities and funding of the proposed programme.

71. The World Conference on Human Rights recommends that each State consider the desirability of drawing up a national action plan identifying steps whereby that State would improve the promotion and protection of human rights.

72. The World Conference on Human Rights reaffirms that the universal and inalienable right to development, as established in the Declaration on the Right to Development, must be implemented and realized. In this context, the World Conference on Human Rights welcomes the appointment by the Commission on Human Rights of a thematic working group on the right to development and urges that the Working Group, in consultation and cooperation with other organs and agencies of the United Nations system, promptly formulate, for early consideration by the United Nations General Assembly, comprehensive and effective measures to eliminate obstacles to the implementation and realization of the Declaration on the Right to Development and recommending ways and means towards the realization of the right to development by all States.

73. The World Conference on Human Rights recommends that non-governmental and other grass-roots organizations active in development and/or human rights should be enabled to play a major role on the national and intemational levels in the debate, activities and implementation relating to the right to development and, in cooperation with Governments, in all relevant aspects of development cooperation.

74. The World Conference on Human Rights appeals to Governments, competent agencies and institutions to increase considerably the resources devoted to building well-functioning legal systems able to protect human rights, and to national institutions working in this area. Actors in the field of development cooperation should bear in mind the mutually reinforcing interrelationship between development, democracy and human rights. Cooperation should be based on dialogue and transparency. The World Conference on Human Rights also calls for the establishment of comprehensive programmes, including resource banks of information and personnel with expertise relating to the strengthening of the rule of law and of democratic institutions.

75. The World Conference on Human Rights encourages the Commission on Human Rights, in cooperation with the Committee on Economic, Social and Cultural Rights, to continue the examination of optional protocols to the International Covenant on Economic, Social and Cultural Rights.

76. The World Conference on Human Rights recommends that more resources be made available for the strengthening or the establishment of regional arrangements for the promotion and protection of human rights under the programmes of advisory services and technical assistance of the Centre for Human Rights. States are encouraged to request assistance for such purposes as regional and subregional workshops, seminars and information exchanges designed to strengthen regional arrangements for the promotion and protection 
of human rights in accord with universal human rights standards as contained in international human rights instruments.

77. The World Conference on Human Rights supports all measures by the United Nations and its relevant specialized agencies to ensure the effective promotion and protection of trade union rights, as stipulated in the Intemational Covenant on Economic, Social and Cultural Rights and other relevant international instruments. It calls on all States to abide fully by their obligations in this regard contained in international instruments.

\section{Human rights education}

78. The World Conference on Human Rights considers human rights education, training and public information essential for the promotion and achievement of stable and harmonious relations among communities and for fostering mutual understanding, tolerance and peace.

79. States should strive to eradicate illiteracy and should direct education towards the full development of the human personality and to the strengthening of respect for human rights and fundamental freedoms. The World Conference on Human Rights calls on all States and institutions to include human rights, humanitarian law, democracy and rule of law as subjects in the curricula of all learning institutions in formal and non-formal settings.

80. Human Rights education should include peace, democracy, development and social justice, as set forth in international and regional human rights instruments, in order to achieve common understanding and awareness with a view to strengthening universal commitment to human rights.

81. Taking into account the World Plan of Action on Education for Human Rights and Democracy, adopted in March 1993 by the International Congress on Education for Human Rights and Democracy of the United Nations Educational, Scientific and Cultural Organization, and other human rights instruments, the World Conference on Human Rights recommends that States develop specific programmes and strategies for ensuring the widest human rights education and the dissemination of public information, taking particular account of the human rights needs of women.

82. Governments, with the assistance of intergovernmental organizations, national institutions and non-governmental organizations, should promote an increased awareness of human rights and mutual tolerance. The World Conference on Human Rights underlines the importance of strengthening the World Public Information Campaign for Human Rights carried out by the United Nations. They should initiate and support education in human rights and undertake effective dissemination of public information in this field. The advisory services and technical assistance programmes of the United Nations system should be able to respond immediately to requests from States for educational and training activities in the field of human rights as well as for special education conceming standards as contained in international human rights instruments and in humanitarian law and their application to special groups such as military forces, law enforcement personnel, police and the health profession. The proclamation of a United Nations decade for human rights 
education in order to promote, encourage and focus these educational activities should be considered.

\section{E. Implementation and monitoring methods}

83. The World Conference on Human Rights urges Governments to incorporate standards as contained in intemational human rights instruments in domestic legislation and to strengthen national structures, institutions and organs of society which play a role in promoting and safeguarding human rights.

84. The World Conference on Human Rights recommends the strengthening of United Nations activities and programmes to meet requests for assistance by States which want to establish or strengthen their own national institutions for the promotion and protection of human rights.

85. The World Conference on Human Rights also encourages the strengthening of cooperation between national institutions for the promotion and protection of human rights, particularly through exchanges of information and experience, as well as cooperation with regional organizations and the United Nations.

86. The World Conference on Human Rights strongly recommends in this regard that representatives of national institutions for the promotion and protection of human rights convene periodic meetings under the auspices of the Centre for Human Rights to examine ways and means of improving their mechanisms and sharing experiences.

87. The World Conference on Human Rights recommends to the human rights treaty bodies, to the meetings of chairpersons of the treaty bodies and to the meetings of States parties that they continue to take steps aimed at coordinating the multiple reporting requirements and guidelines for preparing State reports under the respective human rights conventions and study the suggestion that the submission of one overall report on treaty obligations undertaken by each State would make these procedures more effective and increase their impact.

88. The World Conference on Human Rights recommends that the States parties to international human rights instruments, the General Assembly and the Economic and Social Council should consider studying the existing human rights treaty bodies and the various thematic mechanisms and procedures with a view to promoting greater efficiency and effectiveness through better coordination of the various bodies, mechanisms and procedures, taking into account the need to avoid unnecessary duplication and overlapping of their mandates and tasks.

89. The World Conference on Human Rights recommends continued work on the improvement of the functioning, including the monitoring tasks, of the treaty bodies, taking into account multiple proposals made in this respect, in particular those made by the treaty bodies themselves and by the meetings of the chairpersons of the treaty bodies. The comprehensive national approach taken by the Committee on the Rights of the Child should also be encouraged. 
90. The World Conference on Human Rights recommends that States parties to human rights treaties consider accepting all the available optional communication procedures.

91. The World Conference on Human Rights views with concern the issue of impunity of perpetrators of human rights violations, and supports the efforts of the Commission on Human Rights and the Sub-Commission on Prevention of Discrimination and Protection of Minorities to examine all aspects of the issue.

92. The World Conference on Human Rights recommends that the Commission on Human Rights examine the possibility for better implementation of existing human rights instruments at the international and regional levels and encourages the International Law Commission to continue its work on an intemational criminal court.

93. The World Conference on Human Rights appeals to States which have not yet done so to accede to the Geneva Convention of 12 August 1949 and the Protocols thereto, and to take all appropriate national measures, including legislative ones, for their full implementation.

94. The World Conference on Human Rights recommends the speedy completion and adoption of the draft declaration on the right and responsibility of individuals, groups and organs of society to promote and protect universally recognized human rights and fundamental freedoms.

95. The World Conference on Human Rights underlines the importance of preserving and strengthening the system of special procedures, rapporteurs, representatives, experts and working groups of the Commission on Human Rights and the Sub-Commission on the Prevention of Discrimination and Protection of Minorities, in order to enable them to carry out their mandates in all countries throughout the world, providing them with the necessary human and financial resources. The procedures and mechanisms should be enabled to harmonize and rationalize their work through periodic meetings. All States are asked to cooperate fully with these procedures and mechanisms.

96. The World Conference on Human Rights recommends that the United Nations assume a more active role in the promotion and protection of human rights in ensuring full respect for international humanitarian law in all situations of armed conflict, in accordance with the purposes and principles of the Charter of the United Nations.

97. The World Conference on Human Rights, recognizing the important role of human rights components in specific arrangements concerning some peace-keeping operations by the United Nations, recommends that the Secretary-General take into account the reporting, experience and capabilities of the Centre for Human Rights and human rights mechanisms, in conformity with the Charter of the United Nations.

98. To strengthen the enjoyment of economic, social and cultural rights, additional approaches should be examined, such as a system of indicators to measure progress in the realization of the rights set forth in the intemational Covenant on Economic, Social and Cultural Rights. There must be a concerted effort to ensure recognition of economic, social and cultural rights at the national, regional and intemational levels. 


\section{F. Follow-up to the World Conference on Human Rights}

99. The World Conference on Human Rights recommends that the General Assembly, the Commission on Human Rights and other organs and agencies of the United Nations system related to human rights consider ways and means for the full implementation, without delay, of the recommendations contained in the present Declaration, including the possibility of proclaiming a United Nations decade for human rights. The World Conference on Human Rights further recommends that the Commission on Human Rights annually review the progress towards this end.

100. The World Conference on Human Rights requests the Secretary-General of the United Nations to invite on the occasion of the fiftieth anniversary of the Universal Declaration of Human Rights all States, all organs and agencies of the United Nations system related to human rights, to report to him on the progress made in the implementation of the present Declaration and to submit a report to the General Assembly at its fifty-third session, through the Commission on Human Rights and the Economic and Social Council. Likewise, regional and, as appropriate, national human rights institutions, as well as nongovemmental organizations, may present their views to the Secretary-General on the progress made in the implementation of the present Declaration. Special attention should be paid to assessing the progress towards the goal of universal ratification of international human rights treaties and protocols adopted within the framework of the United Nations system. 